\title{
PERSEPSI DAN IDENTIFIKASI PENYEBAB RUMAH TANGGA MISKIN DI KABUPATEN SITUBONDO
}

\author{
Sasmita Sari ${ }^{1}$ Martono Achmar ${ }^{2}$ \\ Biantaka13@gmail.com \\ Fakultas Pertanian, Universitas Abdurachman Saleh
}

\begin{abstract}
Abstrak
Penelitian ini bertujuan untuk mengetahui; (1) Untuk mengetahui persepsi masyarakat terkait kemiskinan; dan (2) Untuk mengetahui faktor apa saja yang menyebabkan kemiskinan. Model penelitian yang digunakan adalah penelitian kualitatif.dengan metode deskriptif. Data yang diambil menggunakan data primer dan data sekunder. Sampel yang diambil yaitu dengan menentukan key informan dan Teknik snowball sampling dalam menentukan key informan. Metode analisis data yang digunakan ialah analisis Deskriptif (life history) dan Deskriptif (triangulasi data). Hasil penelitian didapatkan bahwa (1) Persepsi masyarakat tentang kemiskinan ialah tingkat perekonomian yang rendah dan sulit untuk mencukupi kebutuhan hidup sehari-hari. kemiskinan berkaitan erat dengan kualitas sumber daya manusia; (2) Faktor penyebab terjadinya kemiskinan dapat dikategorikan dalam beberapa hal diantaranya: (a) Keterbatasan Potensi Sumber Daya Alam; (b) Tingkat Pendidikan; (c) Penghasilan Kerja yang Rendah; (d) Etos Kerja Masyarakat yang Mulai Pudar; (e) Pola Hidup Masyarakat; (f) Biaya Kebutuhan Hidup yang Tinggi; (g) Keterbatasan Sarana Prasarana dan Kelembagaan Ekonomi dan (h) Pembagian Bantuan Pemerintah yang Kurang Merata.

Kata kunci: Persepsi, Rumah Tangga Miskin, dan Analisa Deskriptif
\end{abstract}

\section{PENDAHULUAN}

Kabupaten Situbondo merupakan salah satu kabupaten di Provinsi Jawa Timur yang terdiri dari 17 kecamatan dan 136 desa/kelurahan. Kondisi geografis Kabupaten Situbondo yang terdiri dari masyarakat pesisir yang mayoritas bermata pencaharian sebagai nelayan dan masyarakat non pedesaan yang berprofesi sebagai petani. Angka kemiskinan di Kabupaten Situbondo masih relatif tinggi dengan jumlah rumah tangga miskin mencapai 68.600 keluarga.

Persepsi seseorang selama ini belum tentu sama tentang kemiskinan yang selama ini sudah lama menjadi masalah bagi tiaap daerah. Persepsi adalah pengalaman seseorang tentang suatu objek, peristiwa, atau hubungan yang di perolehnya dari berbagai informasi-informasi yang di dapatkannya lalu menafsirkannya dari informasi yang telah di dapatkannya.

Kemiskinan di Kabupaten Situbondo merupakan permasalahan yang sangat 
sulit di atasi. Berbagai upaya telah dilakukan untuk mengatasi masalah kemiskinan, namun tetap saja tingkat kemiskinan masih tinggi. Kemiskinan yang dialami oleh masyarakat biasanya dipengaruhi oleh beberapa faktor, seperti minimnya lapangan pekerjaan dan rendahnya pendidikan khususnya daerah pedesaan.

Adapun tujuan penelitian ini adalah untuk mengetahui:

1. Persepsi masyarakat terkait kemiskinan?

2. Faktor-faktor yang menyebabkan kemiskinan?

\section{KERANGKA PEMIKIRAN}

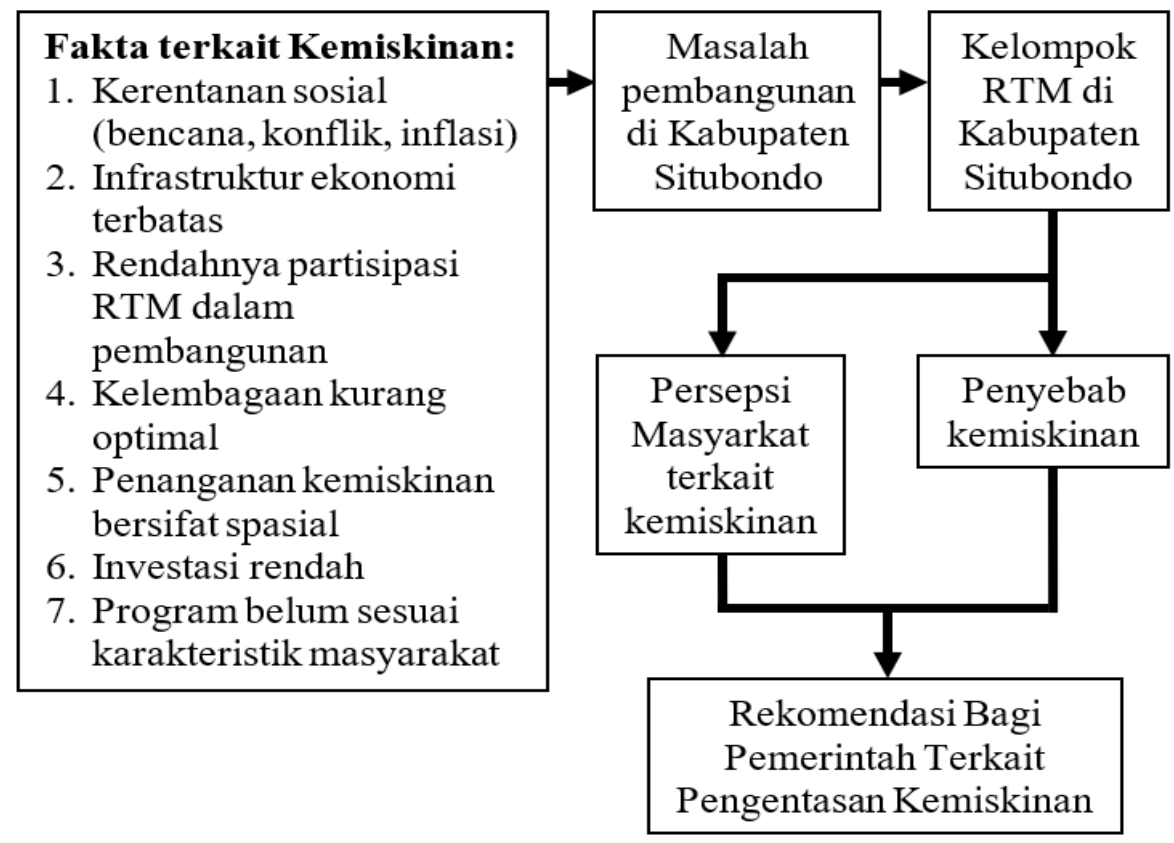

\section{Gambar 1. Skema Kerangka Pemikiran}

\section{METODE PENELITIAN}

Penentuan Penentuan daerah penelitian ini ditentukan secara sengaja (purposive method). Daerah yang di pilih sebagai tempat penelitian ini adalah Kecamatan Besuki Kabupaten Situbondo. Pertimbangan dari pemilihan Kecamatan Besuki tersebut yaitu (1) Kecamatan Besuki merupakan kecamatan 
yang masuk dalam wilayah yang jumlah rumah tangga miskin tertinggi yaitu sebesar 9.065 keluarga, (2) Kecamatan besuki termasuk wilayah yang memiliki topografi wilayah yang unik dengan memiliki wilayah pegunungan dan pesisir; dan (3) Wilayah pegunungan dan pesisir adalah wilayah yang paling banyak dan sering menjadi wilayah yang kebanyakan penduduknya tergolong miskin.

Berdasarkan perumusan masalah dan kerangka konseptual penelitian yang dilakukan adalah penelitian kualitatif yaitu penelitian yang menghasilkan data deskriptif mengenai kata-kata lisan maupun tertulis dan tingkah laku yang dapat diamati dari orang-orang yang diteliti.

Metode pengambilan data yang akan diambil diperoleh dari data primer dan data sekunder. Metode pengambilan contoh yang digunakan dalam penelitian ini adalah pengambilan sampel purposif (purposial sampling), yaitu sampel ditetapkan secara sengaja oleh peneliti yang didasarkan atas kriteria atau pertimbangan tertentu (Faisal, 2009). Pada penelitian ini didasarkan pada informasi yang ingin diperoleh peneliti tentang persepsi dan factor penyebab kemiskinan. Sampel dalam penelitian ini disebut subjek penelitian yaitu yang menjadi informan yang akan memberikan berbagai infomasi yang diperlukan selama proses penelitian. Informan penelitian meliputi beberapa macam yaitu informan kunci (key information), yaitu mereka yang mengetahui dan memiliki berbagai informasi pokok yang diperlukan dalam penelitian, informan utama, yaitu mereka yang terlibat langsung dalam interaksi sosial yang diteliti, dan informan tambahan, yaitu mereka yang dapat memberikan informasi walaupun tidak langsung terlibat dalam interaksi sosial yang diteliti.

Untuk mengetahui persepsi individu pada masyarakat tentang kemiskinan yang terjadi di wilayahnya digunakan alat analisa riwayat hidup (life history). Riwayat hidup (life history) adalah suatu pendekatan yang ada dalam penelitian kualitatif yang biasanya dipergunakan untuk memperoleh bahan keterangan mengenai apa yang dialami oleh individu tertentu di dalam masyarakat yang menjadi obyek penelitian. Riwayat hidup (life history) dalam penelitian ini di 
gunakan untuk melihat bagaimana reaksi, tanggapan, interpretasi, pandangan dari dalam, terhadap diri pada individu masyarakat (Bungin 2009).

Untuk mengetahui faktor apa saja yang menyebabkan kemiskinan digunakan analisis deskriptif (Triangulasi Data). Analisis deskriptif merupakan analisis yang digunakan untuk meneliti status sekelompok manusia, suatu objek, suatu kondisi, suatu sistem pemikiran ataupun suatu peristiwa pada masa sekarang. Tujuan dari analisis ini adalah untuk membuat deskripsi, gambaran atau lukisan secara sistematis, faktual dan akurat mengenai fakta-fakta, sifat-sifat serta hubungan antar fenomena yang diselidiki (Nazir, 2006).

\section{HASIL PENELITIAN DAN PEMBAHASAN}

\section{Persepsi Masyarakat Terkait Kemiskinan}

Kemiskinan sangat identik dengan masyarakat Jawa Timur terutama pada masyarakat pedesaan. Di Kabupaten Situbondo kemiskinan masih menjadi masalah besar dan ditunggu penyelesainnya. Kemiskinan di Kabupaten Situbondo merupakan permasalahan yang sangat sulit di atasi. Berbagai upaya telah dilakukan untuk mengatasi masalah kemiskinan, namun tetap saja tingkat kemiskinan masih tinggi. Perlu adanya evaluasi program pengentasan rumah tangga miskin agar program tersebut dapat berjalan sesuai tujuan. Kemiskinan yang dialami oleh masyarakat biasanya dipengaruhi oleh beberapa faktor, seperti minimnya lapangan pekerjaan dan rendahnya pendidikan khususnya daerah pedesaan. Sehingga sangat berpengaruh terhadap kesejahteraan masyarakat. Hal tersebut dikarenakan belum meratanya pembangunan yang dilakukan oleh pemerintah, sarana dan prasarana serta infrastruktur yang kurang memdai.

Masyarakat yang berada di Kecamatan Besuki Kabupaten Situbondo yaitu kebanyakan merupakan masyarakat miskin yang bermata pencaharian sebagai petani dan nelayan. Kegiatan pertaniannya hanya dilakukan pada saat musim hujan saja dan pada musim kemarau lahan tersebut tidak dapat ditanami karena kesulitan air. Sehingga pada saat musim kemarau masyarakat di Kecamatan Besuki Kabupaten Situbondo khususnya di daerah lahan kering yaitu bekerja 
sebagai buruh bangunan dan merantau kedaerah lain diluar Situbondo. Untuk kegiatan nelayan biasanya dilakukan pada saat air laut tenang dan tidak berombak tinggi, tetapi pada saat gelombang atau ombak air laut tinggi dan pada saat musim paceklik nelayan tidak memiliki pekerjaan tetap.

Persepsi masyarakat di Kecamatan Besuki Kabupaten Situbondo tentang kemiskinan diperoleh dari data wawancara informan dalam penelitian. Berdasarkan data ini diperoleh beberapa jawaban menyangkut tentang kemiskinan pada masyarakat, termasuk faktor-faktor apa saja yang menyebabkan kemiskinan. Persepsi terhadap kemiskinan yang diberikan informan mengenai apa yang dirasakan selama menjalani kehidupan sehari-hari dalam memenuhi kebutuhannya. Hasil wawancara dengan informan tentang kemiskinan hampir semua memiliki jawaban yang sama seperti yang diungkapkan informan ibu Mutmainnah: (3 Juli 2018)

'Miskin ruwa sossah. Pokokna tak nyaman odi' miskin. Gebey ngakan re saare sarah. Tagger ngotang pesse ka tatangge gebey melle beres. Pokok mon lah mosemma panas neka sara se ollea pesse. Mon oreng buto ye alako sabedena".

Menurut informan di atas menjelaskan bahwa kemiskinan yang terjadi karena tidak bisa memenuhi kebutuhan pangan sehari-hari dan memiliki kesulitan untuk menghidupi keluarganya. Hidup miskin rasanya tidak menyenangkan dan terasa susah. Terkadang untuk membeli beras saja sampai berhutang pada tetangga. Hal itu dipertegas dengan hasil wawancara bapak Tajab: (3 Juli 2018)

"Miskin ruwa tak endi' pa apa, mon engkok miskin ongguen soalla tak endi' penghaselan mon lah mosem kemarau neka alako esabe sobung, alako selaen ye tak bisa. Deddina tak bisa gebey kabutuhan keluarga gebey ngakan bik majer sakolana nak kanak".

Kemiskinan yang terjadi dapat disebabkan dari berbegai penyebab, karena lahan kering disaat musim kemarau atau kurang kemampuan fisik kepala rumah tangga untuk bekerja lain sehingga mengandalkan hasil sawah untuk memenuhi kebutuhan pangan dan kebutuhan sekolah, sandang dan lain- 
lain. Hal itu juga dipertegas dengan hasil wawancara dengan nelayan yaitu bapak Edi: (5 Juli 2018)

"Mon e daerah tase' ria yeh mon tak nyare jukok ka tengah tase' ye tak kera olleh pesse. Kabenyaan oreng nelayan neka odikna ebebeh kabbih, kabenyaan miskin. Mon la pas angina raje ombek kia raje ye tak ka tase'. Bede kia se ka tase' tape yeh se kapal-kapalla raje. Mon abek dibi' kapal kennk kenning angin bik ombek bisa tasellem. Nelayan se benyak pessena biasana se kapalla je raje”.

Beda halnya dengan hasil wawancara dengan nelayan di daerah utara Kecamatan Besuki. Menurutnya semua masyarakat pesisir yang berada dipinggir pantai bekerja sebagai nelayan. Hidup di laut hanya melakukan pekerjaan mencari ikan ditengah laut. Kebanyakan nelayan yang memiliki kapal kecil biasanya kehidupannya dibawah rata-rata atau bisa dikatakan miskin. Beda halnya dengan nelayan yg memiliki modal atau uang banyak memiliki kapal yang besar. Perbedaan ukuran kapal ini jika terjadi angin yang kencang dan ombak besar biasanya nelayan dengan kapal kecil enggan untuk melaut, dikarenakan takut kapalnya tenggelam.

Berkaitan dengan konsep di atas, pekerjaan di lingkungan masyarakat di lahan pertanian wilayah selatan Kecamatan Besuki dan wilayah utara khusunya untuk kegiatan masayarakat dibidang perikanan laut pada saat tertentu menghadapi kondisi sulit untuk memenuhi kebutuhan hidup. Kondisi yang seperti itu dialami para masyarakat di Kecamatan Besuki baik itu di wilayah selatan maupun utara untuk memenuhi kebutuhan keluarga.

Pekerjaan masyarakat di lahan pertanian dan wilayah laut dilakukan karena kurangnya lapangan pekerjaan terutama yang memiliki pendidikan dan keterampilan kurang. Menurut Iqbal (2014:45) lebih menekankan pada aspek kurang tersedianya lapangan pekerjaan sehingga masyarakat yang ada di daerah pedesaan juga berupaya menjadi buruh bangunan, kuli toko dan pedagang. Masyarakat tersebut bekerja dengan cara apapun karena jika hanya berdiam di suatu tempat saja maka tidak akan mendapatkan penghasilan. 
Masyarakat di dua wilayah tersebut merupakan salah satu pekerjaan di sektor informal yang mempunyai ciri-ciri salah satuya adalah pola kegiatannya tidak teratur, baik waktu, modal maupun penerimaannya. Dalam melakukan pekerjaannya para masyarakat menentukan sendiri kapan mereka mulai menjadi buruh bangunan, kuli toko dan pedagang setiap harinya maupun hari libur untuk bekerja. Namun biasanya para masyarakat di Kecamatan Besuki mengakhiri pekerjaannya jika sudah mendapatkan upah.

Pada umumnya masyarakat bekerja buruh bangunan, kuli toko dan pedagang karena kurangnya pendidikan dan modal sehingga tidak dapat memilih pekerjaan lain. Hal itu ditegaskan oleh Informan ibu Mutmainnah: (5 Juli 2018)

"alakoa apa pole mon tak esabe dik. Jrengan asakolah tak tammat SMP. Kule bisana perak alako esabe, mon selaen lah tak bisa. Palengan mon lah mosem panas kemarau neka yeh nyare bereng-bereng bekas se bisa ejuel pole. Hasilla bisa gebey kaluarga ngakan re saare”.

Adanya kemiskinan yang disebabkan karena keterbatasan pendidikan juga dipertegas oleh hasil wawancara informan bapak Tajab:

"Ye ngak ria lah dik. Jrengan tak endik ijazah se tenggih. Kle neka perak lulusan SD. Samangken pon omorra tua. Biasana cakanca laen mon naseb pade bik engk' ye bede se alako bangunan deddi kuli. Mon engkok la tak sanggup, tak kuat gebey kak ngangkak. Ye adegeng neka bei sabedena se ejuel"(Tajab 5 Juli 2018).

Pernyataan tentang rendahnya pendidikan informan sehingga mendorong kesulitan dalam mecari pekerjaan juga dijelaskan hasil dari wawancara informan di wilayah utara Kecamatan Besuki yaitu bapak Edi:

“Kule neka tak bisa alako lain dik selaiinna nyare jukok tenga tase'. Ijazah perak SMP teros elang ijazahna dik. Kan la pas sossah. Tak endik keterampilan, ye biasana norok oreng ka' angka' bereng e pasar otabe toko ye elakoni tak rapa asal halal bisa gebey keluarga ebengkoh hasilla" (Edi: 5 Juli 2018).

Berdasarkan haisl wawancara tersebut maka dapat dikatakan bahwa kemiskinan berkaitan erat dengan kualitas sumber daya manusia. Kemiskinan muncul karena sumber daya manusia yang tidak berkualitas, begitu pula sebaliknya. Keterkaitan kemiskinan dengan pendidikan sangat besar karena 
pendidikan memberikan kemampuan untuk berkembang lewat penguasaan ilmu dan keterampilan. Adanya tingkat pendidikan yang rendah dipertegas oleh tokoh masyarakat di wilayah Besuki bagian Selatan yaitu Bapak H. Gofur yang menyatakan:

"Rata-rata pendidikan tertinggi masyarakat di Kecamatan Besuki Kabupaten Situbondo wilayah selatan maupun utara adalah SMP. Namun masyarakat yang berpendidikan SMA hanya sebagian kecil. Mayoritas hanya tingkat SD dan SMP. Hal ini di karenakan kesadaran masyarakat akan pendidikan masih rendah. Disamping itu, mereka juga kesulitan biaya untuk sekolah ke jenjang yang lebih tinggi dari sebelumnya” (H. Gofur: 10 Juli 2018)

Berdasarkan pernyataan beberapa informan dapat dijelaskan bahwa tingkat pendidikan masyarakat masih tergolong rendah sehingga masih banyak masyarakat yang kurang sadar pendidikan. Pendidikan yang rendah akan membuat kemampuan masyarakat juga rendah sehingga ada keterbatasan dalam mencari pekerjaan. Masyarakat Kecamatan Besuki memilih menjadi buruh bangunan, kuli toko dan pedagang pada saat lahan pertanian kering tidak bisa ditanam sehingga lahan petani tidak bisa berproduksi dan sama halnya dengan keadaan di wilayah Besuki bagian utara jika keadaan laut tidak kondusif maka pekerjaan buruh bangunan, kuli toko dan pedagang yang akan menggantikan pekerjaan utamanya tersebut.

Berdasarkan hasil wawancara di atas maka dapat dijelaskan persepsi masyarakat di wilayah Kecamtan Besuki Kabupaten Situbondo tentang kemiskinan ialah tingkat perekonomian yang rendah dan sulit untuk mencukupi kebutuhan hidup sehari-hari. Kemiskinan diakibatkan oleh rendahnya pendidikan, tidak ada lahan yang akan digarap sehingga bekerja dengan berbagai macam pekerjaan asal mendapatkan uang untuk kebutuhan sehari-hari. Ternyata kemiskinan itu tidak terjadi begitu saja melainkan memiliki faktor-faktor yang menyebabkan terjadinya kemiskinan. 


\section{Faktor-Faktor Penyebab Kemiskinan}

Kemiskinan Secara umum kebutuhan konsumsi masyarakat berupa kebutuhan pangan dan non pangan, dimana kebutuhan diantara keduanya sangat berbeda. Pada kenyataannya kondisi diwilayah penelitian, pendapatan yang terbatas lebih dahulu mementingkan kebutuhan konsumsi pangan, sehingga dapat dilihat pada kelompok masyarakat dengan pendapatan rendah yang sebagian besar pendapatannya digunakan untuk memenuhi kebutuhan pangan. Namun demikian seiiring pergeseran peningkatan pendapatan, proporsi pola pengeluaran untuk pangan akan menurun dan meningkatnya pengluaran untuk kebutuhan non pangan. Ternyata kemiskinan itu tidak terjadi begitu saja melainkan memiliki faktor-faktor yang menyebabkan terjadinya kemiskinan. Adapun faktor-faktor penyebab terjadinya kemiskinan dapat dikategorikan dalam beberapa hal berikut ini:

\section{Keterbatasan Potensi Sumber Daya Alam}

Masyarakat miskin belum mampu memanfaatkan sumberdaya alam yang ada karena keterbatasan pengetahuan dan teknologi, serta sifat malas masyarakat untuk bekerja karena faktor sumberdaya alam. Aspek geografis, wilayah di Kecamatan Besuki kurang diuntungkan karena rata-rata curah hujan rendah, sehingga saat kemarau masyarakat tidak memiliki aktifitas ekonomi, kegiatan lebih banyak dilakukan di dalam rumah untuk berkumpul dengan keluarga dan sanak saudara.

Rumah tangga miskin di Kecamatan Besuki Kabupaten Situbondo sebagian besar bekerja sebagai buruh tani (sebagai pekerjaan utama). Petani menyewa atau menggerjakan lahan garapan orang lain, hanya sedikit yang mempunyai sawah sendiri. Luas lahan garapan dengan sistem bagi hasil sekitar 0,1 - 0,25 Ha, sedangkan lahan yang lebih dari $1 \mathrm{Ha}$, hanya beberapa orang saja. Tanaman yang diusahakan lebih pada penyesuaian kondisi biofisik (lahan kering) dengan curah hujan relatif rendah. Di wilayah besuki bagian selatan, terdapat satu sumber air yang dimanfaatkan oleh masyarakat disana, yaitu sumber air yang berasal dari Pegunungan. Namun keberadaan 
sumberdaya air tersebut belum optimal dimanfaatkan rumah tangga miskin dalam aktivitas usahatani, karena kondisi kemiringan lahan yang tidak memungkinkan memanfaatkan air.

Khusus untuk wilayah pesisir, potensi sumberdaya yang dapat dimanfaatkan masyarakat hanya sebatas hasil tangkapan laut saja. Nelayan pada saat musim paceklik atau ombak besar tidak akan pergi melaut, karena ditakutkan terjadi musibah yang tidak diinginkan. Jika kondisi seperti itu biasanya nelayan kebanyakan menganggur yang akhirnya tidak bisa mendapatkan penghasilan dari tangkapan laut untuk mencukupi kebutuhan keluarga.

\section{Tingkat Pendidikan}

Hubungan yang negatif menunjukkan bahwa semakin lama tingkat pendidikan yang dijalani oleh kepala keluarga biasanya akan berimplikasi pada semakin tingginya kualitas sumberdaya manusia, sehingga mereka terhindar dari kemiskinan. Demikian sebaliknya, semakin rendah tingkat pendidikan kepala keluarga maka kualitas sumberdaya manusianya semakin rendah, tingkat produktivitas juga semakin rendah dan akan menyebabkan mereka berpendapatan yang rendah, sehingga tingkat kemiskinan akan semakin meningkat karena ketidakmampuan mereka dalam memenuhi kebutuhan hidup. Oleh karena itu, semakin meningkatnya lama pendidikan kepala rumah tangga akan semakin menurun jumlah keluarga miskin. Ratarata responden pada wilayah penelitian masih berpendidikan SMP dan banyak yang hanya berpendidikan SD maupun tidak tamat SD dan SMP.

Tingkat pendidikan cukup penting pada kategori karakteristik rumah tangga miskin karena tingkat pendidikan akan menjadi modal sumber daya manusia untuk memperoleh pekerjaan yang layak. Kepala keluarga pada rumah tangga miskin rata-rata berpendidikan sekolah dasar dan umumnya tidak mampu menyekolahkan anaknya, sehingga terjadilah lingkaran setan kemiskinan. Tingkat putus sekolah yang tinggi merupakan fenomena yang 
terjadi pada masyarakat pedesaan dan pesisir, termasuk pada komunitas rumah tangga miskin. Mahalnya biaya pendidikan membuat masyarakat miskin tidak dapat lagi menjangkau dunia sekolah atau pendidikan.

Dengan demikian, masyarakat miskin tidak dapat menjangkau dunia pendidikan yang sangat mahal. Untuk makan satu kali sehari saja mereka sudah kesulitan. Akhirnya kondisi masyarakat miskin semakin terpuruk lebih dalam. Tingginya tingkat putus sekolah berdampak pada rendahya tingkat pendidikan seseorang. Dengan begitu akan mengurangi kesempatan seseorang mendapatkan pekerjaan yang lebih layak. Hal ini akan menyebabkan bertambahnya pengangguran akibat tidak mampu bersaing di era globalisasi yang menuntut keterampilan di segala bidang.

\section{Penghasilan Kerja yang Rendah}

Pendapatan merupakan faktor yang sangat penting bagi masyarakat di Kecamatan Besuki. Khususnya pada masyarakat pedesaan wilayah besuki bagian selatan yang kebanyakan bekerja sebagai buruh tani dan petani berlahan sempit serta di wilayah besuki bagian utara yang mayoritas atau hampir sebagian besar penduduknya bekerja sebagai nelayan. Profesi sebagai petani dan nelayan tentunya suatu tuntutan hidup yang sangat berat karena keadaan hidup mereka benar-benar menggantungkan nasibnya kepada keadaan alam. Dimana untuk memenuhi kebutuhan sehari-harinya para petani ataupun nelayan harus mempunyai kegiatan lain selain pekerjaan utamanya tersebut. Dimana pekerjaan alternatif atau pekerjaan sampingan sangatlah diperlukan bagi petani dan nelayan di Kecamatan Besuki untuk meningkatkan pendapatanya. Apalagi dengan pendapatan yang sangat kecil, bahkan tidak mencukupi untuk mencukupi keperluan sehari-hari.

Pendapatan dari hasil pengolahan sawah sangat tidak memungkinkan untuk memenuhi kehidupan petani. Dilihat dari jumlah hasil panen yang begitu minim dan harga penjualan produk pertanian yang begitu rendah, serta perlebgkapan untuk menggarap sawah yang sangat besar biayanya. Selain itu 
pekerjaan Alternatif menjadi penting bagi nelayan ketika laut tidak lagi menyediakan ikan untuk ditangkap, karena pada hakenyataanya pekerjaan sebagai nelayan bergantung kepada kemurahan laut dalam menyediakan sumber dayanya. Hal inilah yang membuat masyarakat di Kecamatan Besuki bagian utara dan selatan kewalahan dalam mengelolah pekerjaannya sehingga membuat mereka terjebak dalam kemiskinan.

\section{Etos Kerja Masyarakat Mulai Pudar}

Faktor ini sangat penting dalam pengaruhnya terhadap kemiskinan. Oleh karena itu, untuk menaikkan etos kerja dan produktivitas masyarakat harus didukung dengan SDA dan SDM yang bagus, serta jaminan kesehatan dan pendidikan yang bisa dipertanggung jawabkan dengan maksimal. Kenyataan bahwa petani dan nelayan merupakan salah satu sosok kemiskinan yang dominan adalah benar. Dahulu etos kerja petani dan nelayan di Kecamatan Besuki bisa dikatakan sangat tinggi, hanya sayangnya mereka bergerak dan berposisi di sektor pertanian sebagai salah satu komoditas yang dihargai rendah, sehingga komoditas yang dibudidayakan tidak mampu memperbaiki kondisi ekonominya dan jika dilihat dari hasil tangkapan nelayan pada saat musim ikan melimpah, harga yang diterima nelayan sangat rendah.

Di sisi lain, pertanian dalam arti luas merupakan satu-satunya sektor yang terlalu banyak intervensi dari pemerintah, bahkan sering kali intervensi pemerintah tersebut kurang menguntungkan bagi petani dan nelayan. Seperti kebijakan harga jual komoditas pangan, kebijakan impor pangan, pencabutan subsidi pupuk dan sebagainya. Akses pembiayaan bagi petani dan nelayan di Kecamatan Besuki dari lembaga keuangan juga belum berpihak dengan alasan sektor pertanian adalah sektor yang memiliki resiko tinggi sehingga banyak petani dan nelayan yang mengakses pembiayaan dari pihak-pihak non lembaga keuangan seperti tengkulak dan pengamba' yang seringkali tidak menguntungkan bagi petani dan sarat akan riba. Berbagai kondisi tersebut diatas menyebabkan banyak masyarakat desa yang bekerja di bidang pertanian dan melaut sngat frustasi, hidup segan mati tak mau. Melanjutkan 
pekerjaannya tapi tak menguntungkan, namun berhenti pun mereka tak punya alternatif lain. Ketika ada kebutuhan yang mendesak, maka tak ada pilihan lain bagi petani selain dengan menjual lahan yang dimilikinya meskipun mereka menyadari bahwa mereka akan kehilangan aset yang paling berharga tersebut. Hal inilah yang kemudian menjadikan masyarakat yang bekerja sebagai petani dan nelayan sudah mulai menunjukkan etos kerja yang menurun.

\section{Pola Hidup Masyarakat}

Tingkat kehidupan masyarakat di Kecamatan Besuki dapat dicerminkan oleh pola pengeluaran rumah tangga miskin. Tinggi rendahnya pendapatan rumah tangga akan berpengaruh terhadap pola pengeluaran rumah tangga. Pengeluaran tersebut dibedakan atas pengeluaran untuk kebutuhan pangan dan kebutuhan non pangan. Bagi rumah tangga miskin yang berpendapatan rendah, maka proporsi pendapatannya akan lebih banyak ditujukan untuk memenuhi kebutuhan pangan yaitu berupa makanan dan minuman. Pola makan masih dalam batas normal yaitu tiga kali sehari. Tetapi untuk menu makanan biasanya tergantung dari beberapa penghasilan yang didapatkan setiap kali panen atau setiap kali melaut. Karena tidak mungkin ketika penghasilan yang rendah namun pengeluaran yang dilakukan melebihi dari apa yang dihasilkan.

Tidak menutup kemungkinan juga dari hasil wawancara, ada sebagian rumah tangga miskin yang berpendapatan rendah juga memiliki pengeluaran pada kebutuhan non pangan seperti kesehatan maupun gaya hidup yang selalu mengikuti jaman. Yang menjadi tolak ukur pada pola gaya hidup yaitu pakaian, dimana ada yang mengatakan bahwa pada saat lebaran tiba beli baju baru dan ada pesta tetangga (perkawinan) juga beli baju baru. Gaya hidup yang berarti persamaan status kehormatan yang ditandai dengan konsumsi terhadap simbol-simbol gaya hidup yang sama. Estetika realita melatarbelakangi arti penting gaya hidup anak muda dipedesaan saat ini yang juga didorong oleh dinamika pasar modern dengan adanya model pakaian, 
baru, gaya baru, sensasi dan pengalaman baru. Gaya hidup yang ditawarkan berbagai media saat ini adalah ajakan bagi khalayak untuk memasuki apa yang disebut budaya konsumer.

\section{Biaya Kebutuhan Hidup yang Tinggi}

Petani dan Nelayan adalah tombak awal pengadaan pangan bagi masyarakat dan negara, maka tidaklah pantas bila petani dan nelayan harus selalu menjadi korban atas pangsa pasar yang tidak adil bagi kebutuhannya. Petani dan Nelayan tidak boleh dilupakan segala jasa dan pekerjaannya yang sampai saat ini masih sangat mulia memenuhi kebutuhan pangan masyarakat dan negara. Kenaikan BBM (Bahan Bakar Minyak) selalu menjadi momok untuk sebuah keputusan harga kebutuhan masyarakat, terutama kepada kebutuhan sembilan pokok (Sembako).

Melonjak tingginya biaya kehidupan di suatu daerah adalah sebagai akibat dari tidak adanya keseimbangan pendapatan atau gaji masyarakat. Tentunya kemiskinan adalah konsekuensi logis dari realita di atas. Hal ini bisa disebabkan oleh karena kurangnya tenaga kerja ahli dan banyaknya pengangguran. Kemiskinan memang salah satu masalah yang timbul akibat pendidikan yang rendah hanya mengandalkan pengetahuan yang terbatas, dan harga kebutuhan yang melambung tinggi sehingga biaya hidup semakin tinggi. Kebutuhan harga pokok sekarang sudah melambung tinggi dengan adanya harga (BBM) yang naik, ini menjadi beban bagi ibu-ibu rumah tangga sehingga mereka memutar otak membantu suaminya untuk mencukupi kebutuhan sehari hari. Kenaikan BBM sudah pasti akan diikuti melambungnya harga bahan kebutuhan pokok, akibatnya daya beli masyarakat berkurang, awalnya rumah tangga miskin hanya mampu makan sehari tiga kali kini mereka jadi makan satu kali untuk sehari sebab mereka sudah tidak mampu lagi membeli bahan kebutuhan pokok yang harganya semakin mahal. 


\section{Keterbatasan Sarana Prasarana dan Kelembagaan Ekonomi}

Keterbatasan sarana prasarana dan kelembagaan ekonomi juga dapat menyebabkan tingkat kemiskinan didaerah bertambah. Keadaan seperti ini mengakibatkan terisolasi, perputaran modal kurang, bagi hasil yang tidak adil, dan tingkat upah yang relatif rendah. Datang dari luar kemampuan orang yang bersangkutan, seperti birokrasi atau peraturan-peraturan resmi yang dapat menghambat seseorang yang dapat memanfaatkan sarana prasarana dan kelembagaan ekonomi. Kemiskinan model ini sering kali di istilahkan dengan kemiskinan struktural. Kemiskinan terjadi bukan di karenakan "ketidakmauan" rumah tangga miskin untuk bekerja (malas), melainkan karena "ketidakmampuan" sistem dan struktur sosial dalam menyediakan kesempatan-kesempatan yang memungkinkan rumah tangga miskin untuk bekerja.

Lembaga ekonomi adalah faktor yang berpengaruh dan bisa menjadi salah satu kendala utama bila pasar tidak berkembang di sautu wilayah. Dalam hal ini tentunya petani dan nelayan perlu wadah atau tempat untuk menyalurkan atau memasarkan hasil tangkapanya, dan untuk mengupayakan usaha tersebut. Selama ini belum ada lembaga ekonomi atau lembaga perkumpulan petani atau nelayan yang bertugas menaungi keperluan dan menyalurkan hasil produksi di Kecamatan Besuki. Untuk mengembangkan pasar bagi produk-produk yang dihasilkan petani dan nelayan di Kecamatan Besuki maka upaya yang dilakukan adalah melalui pengembangan koperasi atau usaha bersama yang berbadan hukum agar hasil produksi yang selama ini harga ditentukan oleh tengkulak dapat diatasi. Selama ini petani dan nelayan selalu dipermainkan masalah harga yang relatif murah dan tidak memiliki posisi tawar yang kuat untuk membentuk harga. Struktur pasar yang tidak menguntungkan ini disebabkan karena informasi yang kurang mengenai harga. Sehingga harga lebih sering dimonopoli oleh para tengkulak, dimana mereka membeli dengan harga murah dan menjualnya kepada eksportir dengan harga yang berlipat ganda. Adanya keperasi dimana mereka 
yang bekerja sebagai petani atau nelayan menjadi anggota koperasi tersebut, sehingga dari kegiatan usahanya dapat dijual melalui koperasi dengan harga yang tidak merugikan petani ataupun nelayan.

\section{Pembagian Bantuan Pemerintah Kurang Merata}

Petani dan nelayan selalu menjadi buah bibir setiap kali menyinggung masalah pangan didalam negeri. Sebaliknya, kesejahteraan diantara petani dan nelayan jarang dibicarakan bahkan hampir dilupakan, padahal mayoritas lebih dari 50\% masyarakat Indonesia hidup dari sektor pertanian. Rumah tangga miskin di Kecamatan Besuki menyadari bahwa pemerintah daerah tidak pernah berhenti memberikan perhatian untuk mensejahterakan masyarakatnya. Optimalisasi dan efisiensi program-program yang melindungi rumah tangga miskin terus digalakkan. Hal ini sebagai bentuk kewajiban dari pemerintah daerah yang harus dilaksanakan sebagaimana yang selalu terlihat dalam program-programnya. Akan tetapi program atau kebijakan pemerintah tersebut belum bisa mengatasi masalah kemiskinan khususnya bagi para petani yang memiliki lahan sempit dan nelayan yang masih sangat tradisional.

Pembagian bantuan pemerintah yang kurang merata dapat menyulitkan akan terpenuhinya kebutuhan pokok dan jaminan keamanan untuk rumah tangga miskin, juga secara tidak langsung mematikan sumber pemasukan dari rumah tangga miskin. Bahkan di sisi lain masyarakat atau rumah tangga miskin masih dan terbebani oleh pajak negara. Salah satu contoh bantuan pemerintah yang tidak merata yaitu dari hasil wawancara dengan salah satu rumah tangga miskin yaitu rumahnya yang sudah mulai rusak atapnya dan sudah bocor dan dindingnya yang sudah mulai hancur tidak mendapat bantuan dari pemerintah, tetapi yang anehnya orang yang mempunyai barang elektronik dan mempunyai hewan ternak yang mendapatkan bantuan. 


\section{KESIMPULAN DAN SARAN}

\section{Simpulan}

1. Persepsi masyarakat di wilayah Kecamatan Besuki Kabupaten Situbondo tentang kemiskinan ialah tingkat perekonomian yang rendah dan sulit untuk mencukupi kebutuhan hidup sehari-hari. kemiskinan berkaitan erat dengan kualitas sumber daya manusia. Kemiskinan muncul karena sumber daya manusia yang tidak berkualitas, begitu pula sebaliknya. Keterkaitan kemiskinan dengan pendidikan sangat besar karena pendidikan memberikan kemampuan untuk berkembang lewat penguasaan ilmu dan keterampilan.

2. Faktor penyebab terjadinya kemiskinan dapat dikategorikan dalam beberapa hal diantaranya: (a) Keterbatasan Potensi Sumber Daya Alam; (b) Tingkat Pendidikan; (c) Penghasilan Kerja yang Rendah; (d) Etos Kerja Masyarakat yang Mulai Pudar; (e) Pola Hidup Masyarakat; (f) Biaya Kebutuhan Hidup yang Tinggi; (g) Keterbatasan Sarana Prasarana dan Kelembagaan Ekonomi dan (h) Pembagian Bantuan Pemerintah yang Kurang Merata.

\section{Saran}

Upaya pengentasan rumah tangga miskin melalui pengembangan sumberdaya lokal yang berbasis kelembagaan dalam konteks pemberdayaan masyarakat dilakukan 5 (lima) pendekatan, yaitu faktor politik dan kebijakan, ekonomi, sosial, budaya serta kelembagaan

1. Faktor politik dan kebijakan pemerintah: terbentuknya komitmen politik yang kuat dan konsisten dari para penentu kebijakan (policy maker), melalui: (a) penyusunan program dan strategi penanggulangan rumah tangga miskin secara berkelanjutan dan berkesinambungan; (b) pengembangan ilmu pengetahuan dan teknologi seyogyanya tidak hanya terfokus pada "research" murni, namun lebih mengarah pada "action research"; (c) upaya mengurangi secara bertahap kepentingan-kepentingan bersifat ego sectoral dan diarahkan pada pemenuhan dan kepentingan rumah tangga miskin; (d) menyusun indikator-indikator keberhasilan dan kegagalan dari setiap program pengentasan rumah tangga 
miskin dengan melibatkan pihak lain; dan (e) mensinergikan programprogram pengentasan rumah tangga miskin antar instansi terkait.

2. Faktor ekonomi: berdasarkan karakteristik potensi di Kecamatan Besuki nampak bahwa aktivitas pertanian dan perikanan laut merupakan sumber pertumbuhan perekonomian yang perlu digerakkan. Pilihan strategisnya adalah mengembangkan pengusahaan pertanian dan perikanan laut secara integrated atau terpadu.

3. Faktor Sosial: dibutuhkan upaya mengatasi ketidakberdayaan rumah tangga miskin melalui: (a) intensitas pemberian bantuan biaya untuk membeli kebutuhan pangan, semacam raskin; dan (b) rehabilitasi rumah tinggal masyarakat miskin yang dinilai kurang layak dari sisi kesehatan dan pertumbuhan balita.

4. Faktor Budaya: kekuatan rumah tangga miskin, terletak pada kemampuan dalam menjalin ikatan kerjasama antar sesama melalui tradisi gotong royong., Untuk itu, tradisi tersebut perlu didorong oleh pemerintah setempat ke arah pengembangan kelembagaan ekonomi. Penguatan kelembagaan permodalan usaha berbasis budaya lokal adalah pilihan strategis guna mendukung pengembangan potensi sumberdaya alam.

5. Faktor Kelembagaan: pengentasan rumah tangga miskin dilakukan melalui pendekatan kelembagaan (lembaga pemberdayaan, baik gotong-royong atau rembug desa dan arisan periodik, baik mingguan maupun musiman, maupun lumbung padi. Pola tersebut menciptakan interaksi dinamis antara kelompok miskin dan pekerja sosial sebagai pendamping untuk secara bersama-sama menghadapi beragam tantangan seperti; (a) menyusun kegiatan yang terfokus pada perbaikan kehidupan sosial ekonomi; (b) mengelola potensi sumberdaya lokal agar memiliki nilai ekonomi; (c) identifikasi lebih mendalam dan menemukan solusi terhadap masalah sosial; dan (d) mendorong pengembangan akses guna pemenuhan setiap kebutuhan, termasuk akses dalam permodalan atau kredit lunak yang difasilitasi pemerintah dan lembaga keuangan. 


\section{DAFTAR PUSTAKA}

Badan Pusat Statistik. 2017. Kabupaten Situbondo Dalam Angka. Situbondo: Badan Pusat Statistik.

Bungin, Burhan. 2009. Analisis Data Penelitian Kualitatif. PT. Raja Grafindo persada: Jakarta.

Faisal, A. 2009. Metode Penelitian. Jakarta: Erlangga

Nazir, M. 2006. Metodologi Penelitian. Jakarta: Ghalia.

Suyanto, Bagong. 2006. Kemiskinan dan Kebijakan Pembangunan. Aditya Media: Yogyakarta.

Tulung, Freddy H. 2011. Program Penanggulangan Kemiskinan Kabinet Indonesia Bersatu II. Kementerian Komunikasi Dan Informatika Ri Direktorat Jenderal Informasi Dan Komunikasi Public: Jakarta

World Bank. 2006. Era Baru dalam Pengentasan Kemiskinan di Indonesia. Ikhtisar. Jakarta : The World Bank Office Jakarta. 